\title{
1. 次世代画像メディアの展望
}

\section{1-1＼cjkstart情緒と雑音のギガ社会}

\section{月尾嘉男}

\section{80 年代はキロの時代}

1977 年 4 月に, 組立てられた製品としては世界最 初のパーソナルコンピュータ「アップル II」がアメリ カで発売されたこの機械には内部記憶装置として $16 \mathrm{~KB}$ (キロバイト)の RAM と $12 \mathrm{~KB}$ の ROM が標 隼装備されており， RAM は $48 \mathrm{~KB}$ まで拡張可能で あった 外部記憶装置は当初はオーディオカセットテ ープレコーダを利用していたが，翌年には 8 インチの フロッピーディスク装置が発売され，その記憶容量は $640 \mathrm{~KB}$ であった

日本では, 2 年遅れた 1979 年 9 月に, 国産として は最初のパーソナルコンピュータ「PC 8001」が発売さ れたが,この内部記憶装置は $24 \mathrm{~KB}$ の RAM と 24 $\mathrm{KB}$ の ROM が標隼装備であった 600 ボーのオーデ イオカセットインタフェースもあらかじめ用意されて いたが，しばらくして $640 \mathrm{~KB}$ の記憶容量を持つ 8 イ ンチのフロッピーディスクが一般に使用される外部記 憶装置になった

これら初期のパーソナルコンピュータの計算能力は 毎秒数万の命令を処理できる程度であり, 技術表現で は数 $10 \mathrm{KIPS} と い う$ 単位になるその 100 万倍以上 の計算能力を持つ現在のスーパコンピュータと比較す れば，玩具のような機械であるが，コンピュータを一 般の人間にとって身近な存在にしたということでは偉 大な革命であった それ以前, コンピュー夕は教育機 関や研究施設に在籍する一部の専門の人間にしか利用 の機会のない装置であったが，これらのパーソナルコ ンピュータによって，ごく一般の人間が日常に接触す る情報環境の一部になったのである それは「アップ

\section{$\dagger$ 東京大学 工学部}

"A Survey of the Next Generation Imaging Technology, Emotion and No1se-Key Concept of the Giga Age" by Yoshio Tsukio (Faculty of Engineering, The University of Tokyo, Tokyo)
ルII」が当時の多数の人間に熱狂をもって歓迎され， わずか 6 年間で 100 万台も販売されたという事実が証 明している

情報環境といえば，情報処理の部分と同時に，情報 伝送の部分が重要である 長年にわたり，一般の人間 が使用する情報伝送手段はアナログ伝送の電話回線だ けであったが, 1980 年代になり, ディジタル伝送ネ ットワークとして, 日本では INS の実験が東京の三 鷹を中心とした一帯で実施され，その発展した NISDNの敷設が全国規模で開始された その伝送容量 は毎秒 $64 \mathrm{~Kb}$ (キロビット)であり，ここ当分の期間， このネットワークが一般の企業や個人が情報伝送に使 用する環境になりつつある

このように検討すると，1980 年代に一般の人間が 普通の状態で利用できた情報環境の量的な単位は, 情 報処理能力が毎秒 1000 の命令を処理する KIPS(キ ロ・インストラクション・パー・セカンド), 情報記憶 能力が装置あたり 1000 バイトを記憶できる KBPU (キロ・バイト・パー・ユニット), 情報伝送能力が毎 秒 1000 ビットの情報を伝達できる $\operatorname{KbPS}$ (キロ・ビッ ト・パー・セカンド）という単位で表現される状態て あったが，重要なことは，いずれも「キロ」という共 通する接辞で表現されるということである

\section{2. メガに飛躍した 90 年代}

1983 年 2 月に, サン・マイクロシステムズというア メリカのベンチャー企業から「サン 1 という小型の コンピュータが発売され，既存のコンピュータ世界に 激震をもたらした この種類のコンピュータはワーク ステーションといわれ，メインフレームコンピュータ をタイムシェアリングで利用したり，ミニコンピュー タで計算したりするのと同等の計算環境を数 100 万円 で提供できるということになり，教育機関や研究機関 を中心に急速に普及した 
これらのワークステーションは，コード体系が公開 されているUNIX というオペレーションシステムを 使用するというオープンシステムという発想と, 少数 の命令のみで高速に駆動する RISC というマイクロプ ロセッサを使用するというダウンザイジングという発 想を特徴とし，これらの技術により価格が急速に低下 し，10 年間で世界のコンピュータ市場の半分を占有 するまでになり, コンピュータの技術体系と産業構造 を一変させてしまった。 その革命のなかで, 各社の独 自のオペレーティングシステムに固執したメインフレ ームコンピュータに依存していたアイ・ビー・エムや ユニシスなどのコンピュータ会社は急速に業績を悪化 させる一方, 優秀なワークステーションを発表してき たサン・マイクロシステムズやシリコン・グラフィッ クスなどのコンピュータ会社が一気に成長するという 激動が進行している.

これらのワークステーションに標準装備されている 内部記憶装置は最小でも数 $\mathrm{MB}$ (メガバイト)の RAM で, 拡張すれば数 $10 \mathrm{MB}$, 外部記憶装置の磁気ディ スク装置の記憶容量は数 $10 \mathrm{MB}$ から数 $100 \mathrm{MB}$ にな つている. 計算能力も初期の「サン 1 」では毎秒 50 万 の命令を処理できる程度であったが， 5 年後の 1986 年 2 月に発売された「サン 4 」になると毎秒 700 万に, さらに 1992 年 5 月に発売された「スパーク・ステーシ ヨン」では毎秒 4 億の命令を処理できるまでに飛躍し ている. 毎秒 100 万の命令を処理する計算能力を MIPS というが，その表現を使用すれば，ワークステ ーションは数 100 MIPS の能力の情報環境を提供して いるということになる.

初期のワークステーションはパーソナルコンピュー 夕のように個人が自由に購入するにはやや高価であっ たが，技術革新により価格は急速に安価になりつつあ り, 最近の最小構成のワークステーションの基本価格 は数 10 万円にまでなって, 充分に個人使用の対象に なるものである。一方, パーソナルコンピュータの能 力の向上も顕著で, 内部記憶装置の容量についても計 算速度についても, 両者の境界は次第に曖昧になりつ つある。

また，情報環境のもうひとつの側面である情報伝送 については, 1990 年代の中頃から敷設が本格開始さ れる光ファイバを使用したディジタル伝送ネットワー ク B-ISDN が利用できるようになるが, これは毎秒 $150 \mathrm{Mb}$ (メガビット)から $600 \mathrm{Mb}$ の情報を伝送する 能力を持つものである.

いずれにしても, 1990 年代に一般の人間が会社や 家庭など日常生活で利用できる情報環境は, 情報の処
理能力が毎秒 100 万の命令を処理できる $\operatorname{MIPS}$ (メ ガ・インストラクション・パー・セカンド), 情報の記 憶能力が装置あたり 100 万バイトの情報を記録できる $\operatorname{MBPU}$ (メガ・バイト・パー・ユニット), 情報の伝送 能力が毎秒 100 万ビットの情報を伝送できる MbPS (メガ・ビット・パー・セカンド) という単位で表現さ れることになるが, ここでも重要なことは，いずれも 「メガ」という共通する接辞で表現されるということで ある。

\section{3. ギガに突入する 21 世紀}

1980 年代から 1990 年代の 10 年間に, 一般の人間 が日常に接触する情報環境は, 処理能力についても, 記憶能力についても, 伝送能力についても,「キロ」 から「メガ」へと 1000 倍の飛躍をしたことになるが， この傾向を単純に延長すれば, 2000 年代には,さら に 1000 倍の「ギガ」という単位が情報環境を表現する 共通の接辞になると予測される。最初に「ギガ」時代 の単位の説明をしておけば, 毎秒 10 億の命令を処理 できる計算能力が GIPS(ギガ・インストラクション・ パー・セカンド), 装置あたり 10 億バイトの情報を記 録できる能力が GBPU(ギガ・バイト・パー・ユニッ 卜), 毎秒 10 億ビットの情報を伝送できる能力が GbPS（ギガ・ビット・パー・セカンド）という単位で 表現される。

現在のスーパコンピュータは数 10 GIPS 程度の処 理能力を持つが, 2000 年代には, その程度の能力を 持つコンピュータを個人が卓上に設置して, 日常生活 で利用できるようになると予測される。サン・マイク ロシステムズの技術開発の中心人物であるビル・ジョ イが提唱している「ジョイの法則」という, ワークス テーションの処理能力目標を設定する数式がある.

\section{$\mathrm{MIPS}=2^{(\mathrm{YEAR}-1984)}$}

と表現されるが, この数式で予測すれば,すでに 1994 年に 1000 MIPS, すなおち 1 GIPS 以上になり, 2000 年には 65 GIPS に到達する.

現在の市場に出回っている最新の集積回路記憶素子

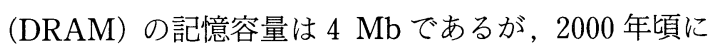
は $256 \mathrm{Mb}$ になり,さらに数年すれば $1 \mathrm{~Gb}$ (ギガビッ ト)になると予測されている。また，外部記憶装置と して主流になると想定される光磁気ディスク装置は, 現状で $1 \mathrm{~GB}$ (ギガバイト)程度であるが, 数年で数 GB になり, 2000 年頃には $10 \mathrm{~GB}$ にまで到達すると 予測されている.これらを前提とすれば, 21 世紀初 頭のワークステーションやパーソナルコンピュータ は, 内部記憶装置として数 GB, 外部記憶装置として 
数 $10 \mathrm{~GB}$ の能力を持つものが登場するとして間違い はない.

伝送技術の分野でも同様の技術進歩が期待されてお り, 現在でも数 GbPSの技術は存在しているが, 数 年で数 $10 \mathrm{GbPS}$ にり，2000 年頃には数 $100 \mathrm{GbPS}$ の技術開発が達成されると予測されている。それらが 現実のサービスとして提供されるのは, 日本では前述 した B-ISDN で数 $100 \mathrm{MbPS}$ の容量であるが, アメ リカでは昨年発表された国家情報基盤整備計画（NII） で 4 GbPS の容量を持つネットワークの敷設を想定し ており, 日本も追随してギガビットネットワークの構 想を策定する準備が進行している。

このように検討してくると, やはり 21 世紀初頭の 情報技術は「ギガ」を単位とするものになっているこ とは確実であり，これからの情報社会の行方を検討す るためには, 現状の「メガ」を基礎単位とした社会で はなく，その 1000 倍の能力をもつ「ギガ」を基礎単位 とする情報環境が個人の作業環境や日常生活に提供さ れる社会を想定する必要がある。

\section{4. ギガ社会予測の困難}

簡単に 1000 倍というが, その飛躍による変化を予 測することはそれほど容易ではないことを, 以下の比 喻で説明したい. 会社で仕事に使用している情報環境 や家庭で利用する情報環境がメガ単位の人間を時速 4 $\mathrm{km}$ で道路を歩行している状態とする．この歩行して いる人間が, 突然に超音速戦闘機を操縦して道路上空 を時速 $4000 \mathrm{~km}$ で飛行するようになったとすると, それがギガ単位の状態である. 情報の単位と速度の単 位が比例しているわけではないが, 行動できる空間の 範囲や周囲の風景の認識は, まったく異質なものにな るということは充分に予想できるはずである.

同様に，メガ単位の情報環境に生活する人間を年収 1000 万円のサラリーマンと仮定してみる。情報の単 位と金銭の単位に明確な関係があるわけではないが, 単純に比例させてみれば，この人間が年収 100 億円の 異常な金持になった状態がギガ単位の情報環境に生活 する状態ということになる。これから 10 年ほどで到 来するギガ単位の情報社会を想像することは, サラリ ーマンに世界に数人もいるかいないかという金持の生 活を想像せよといい，地上を歩行するしか手段のなか った江戸時代の人間に現代の移動環境を想像せよとい うのに相当するのである.

そして, 現在の時点で, ワークステーションなどの メガ単位の情報環境に接触しているのは, ほんの少数 の人間であり, 会社でパーソナルコンピュータで会計
処理を行い, ワードプロセッサで文書作成を行い， N -ISDNでデータを送信しているのが，ほとんどの人 間であるとすれば, 飛躍は「メガ」から「ギガ」とい う 1000 倍の単位ではなく, 「キロ」から「ギガ」への 100 万倍の飛躍ということになり，想像する距離はさ らに拡大する。そのような想像が筆者にできるわけで はないが, 予想されそうな変化を以下に検討してみた い.

\section{5. 画像優先社会の到来}

だれもが容易に予測できる変化は, 画像による情報 処理や情報伝達が社会の主流になることである．風景 の描写のように視覚で認識した情報の伝達, 道順の案 内のように空間の情報の伝達など, 人間にとって画像 で伝達した方が容易な内容は多数ある。しかし, 現実 の日常の情報伝達は文字を中心とした文書や，音声を 中心にした電話などが主流である。それは，抽象情報 を操作できるという人間固有の能力を駆使していると 理解できなくもないが，これまで情報を伝達する現実 の手段を制約していたことの反映でもある.

一例として, サッカーの試合で, ある選手が得点し た様子を伝達する場合を, その内容によって比較して みると, だれが得点したかという結果だけを文字で伝 達しようとすれば，せいぜい数 10 バイトで表現でき るが,これを音声にして伝達しようとすると数 $10 \mathrm{~KB}$ と 1000 倍以上の容量が必要となり, 得点の瞬間をカ ラー写真で表現すれば数 $100 \mathrm{~KB}$ と 1 万倍以上の情報 を伝達しなければならない。 さらに, 数秒の動画で得 点の様子を表現すれば数 $10 \mathrm{MB}$ が必要となり, 文字 の 100 万倍という膨大な情報を伝達しなければならな i.

人間にとっては後者ほど理解が容易であるが, 従来 は膨大な容量を必要とする画像を安価に自由に伝達す る手段が社会に提供されておらず，その方式が抑制さ れていたのである. しかし最近では画像社会への変化 が始まり, 例えば，企業が就職候補の学生に送付する 企業案内は, かつては文字や数字を中心とする文書で あったが, 次第に劇画などで業務内容を紹介する企業 が増大し, 最近では, ビデオテープレコーダの普及を 前提としてビデオテープを送付してくる企業が主流に なりつつある .

それは若者がカール・マルクスの『資本論』を文字 への翻訳ではなく劇画への翻案で理解し, 毎日のニュ ースを新聞ではなくテレビで入手するという堕落を反 映していると批判する意見もあるが, 人間にとって理 解しやすい方向へ情報伝達が発展していると理解する 
こともできる。いずれにせよ，ギガを基礎単位とする 社会は，画像を伝達する技術の制約が希薄になる社会 とすれば，この方向は促進されると予測することがで きる、そして，その方向が真実とすれば，画像を中心 として情報が伝達される社会の本質を明確にすること が必要である。

\section{6. 情緒が主役の時代}

現代では情報という言葉が日常何気なく使用されて いるが，これは随分と矛盾した意味をもっている。新 聞の記事は疑問の余地なく情報である。この情報とい う意味は，その内容が「正確」で「客観」であること は当然として，「希少」かつ「迅速」ということであ る、巨大な活字で朝刊の一面に政治事件が報道される ことがあるが，このような報道は一紙だけ独占のとき と, 同様な記事が各紙の一面に掲載されているときと では価值に雲泥の相違があるし，一紙だけが出遅れて 夕刊にしか揭載できなかったのでは, 担当記者が減俸 処分になるほど価值は低落してしまう。この事例のよ うに, 情報の価值は希少なものが迅速に伝達されると きほど価值があるというのが常識である.工学分野の 情報理論の場合も，情報の量的な意味は，一定の集団 のなかで，その情報が伝達された人数の逆数に比例す るような定義になっている.

それでは同様に文字で表現される小説はなにかとい えば，これも情報である。しかし，その内容は正確か つ客観かといえばそうではなく，著者の「主観」を明 確に反映した虚構であり, 表現されている内容はかな り「曖昧」である。一方, 新聞の記事は 3 日もすれば 価值が急速に低下してしまうが, 小説は数年たっても 価值があるものもあるし，古典といわれるようなもの は時間とは関係なく長期にわたって価値を保持してい る.さらに新聞との重要な差異は, その価值が希少と いうことに関係ないどころか, より多数の人間に共有 されるほど価值が増大してくるという性質である。あ る小説がベストセラーとの評判になればなるほど部数 が増大するが, これは希少でなくなるほど価値が増大 することであり，新聞の記事とはまったく反対の価值 構造を持っていることになる.

このように，日常生活で「情報」という言葉で表現 されている対象には，「客観」「正確」「迅速」「希少」 を特徵とするものと, 完全に反対の「主観」「曖昧」「緩 慢」「普遍」という性質により価值があるものとがある が，両者を明確に区別せずに情報と表現しているとこ ろに様々な混乱の原因がある，そこで両者を区別をす るために, 前者は「情報」のままにしておいて, 後者
は「情緒」と命名してみると，現代社会は性質が対極 をなすような情報と情緒が渦巻いている社会といえる のである .

さらに重要なことは，情報と情緒は性質が対極にあ るだけではなく, その使用される目的も極端に相違し ていることである．巨大地震による災害の状況を伝達 する場合を想定してみる，新聞の一面では，地震発生 の時刻, 災害発生の場所, 被害規模の推定などが地図 や数字とともに報道されるが, 三面になると, 被災し た家族の状況, 救助する隊員の言葉, 取材した記者の 感想などが写真や地図とともに記事になる。どちらも 同一の事件の報道であるが，それぞれの目的や意図は 大幅に相違する．前者は「客観」「正確」な表現により 「希少」な災害の事実を「迅速」に伝達しょうとする「情 報」であるが, 後者は「主観」「曖昧」な表現により悲 惨や脅威という「普遍」の感情を伝達しょうとする「情 緒」である.

当然であるが，それぞれの記事への読者の反応も相 違する。それを「情報」として理解する人間は，どの ようにすれば救援物資を現地へ送付できるかを検討し たり，どのような企業の株式を購入すれば利益が期待 できるかを計算したりするが，「情緒」として理解す る人間は, 被災した家族に同情したり, 自然の威力に 脅威したりするのである。すなわち，「情報」は援助 の実行とか株式の購入という行動に直結するのに対比 して,「情緒」は被害への同情とか自然への丳威とい う感性に作用するという相違である。

それでは，前述したギガ社会で多用される画像は何 を伝達しているかを考察してみたい. 企業の営業成績 をグラフにした画像が好例であるが，画像が「客観」 「正確」「迅速」「希少」という性質の情報を伝達できな いわけではない。しかし, このようなグラフは詳細な 営業成績の内容を表現しているというょりは, 概略の 営業成績の傾向を表現しているといった方がいい. 右 下がりのグラフは, 企業の次期戦略を検討するという 行動に有益というょりは, 社員の奮起努力を促進する という精神に有効なのである. 右下がりのグラフを作 成する基礎には, 客観かつ正確な数字が必要なことは 当然であるが, あらゆる場合に数字そのものを提示し ていた従来の状態から, それらの数字を容易に画像に 変換できる情報処理の技術が普及することにより, 情 緒に作用する情報伝達が活発になると理解するのがい い.

1960 年代の教祖であったカナダの社会学者マーシ ヤル・マクルーハンは, 情報を伝達する手段には, 正 確な事実を伝達するクールメディアと人間の感情に作 
用するホットメディアとが存在すると喝破したが，こ の分類を規範とすれば，これまでの文字を中心とする クールメディア主導のメガ社会から, 画像を中心とす るホットメディア主導のギガ社会への転換が始まりつ つあるということになる。

\section{7. 雑音が決定する時代}

昨年の情報社会の重要な話題のひとつは, 政治活動 と情報媒体の関係であった。 とりわけ興味のある争点 となったのは, 特定の人物の画像を放映したことが特 定の情報の伝達の意図と関係があるかどうかというこ とであった，二人の国会議員が議場でヒソヒソと話合 っている画像を何度も放映したことが，その打合せの 内容とは関係ない意図を伝達するためであったのかど うかが, 国会での証人喚問で問題とされた。「どうい うことを話合っているかということと関係ないあるイ メージを伝達するために映像を使用したのか」という 主旨の質問に，「連日発生している事象をテレビカメ ラが撮影し，それを提供したのであって，ある特定の メッセージの伝達を意図したのではない」というのが 答弁の内容である.

これは，前述の情報と情緒の関係で説明すれば，質 問した人間は客観・正確な「情報」を伝達するのがテ レビ放送の使命であるのに, 主観・曖昧な「情緒」を 放送するのは扔かしいのではないかと詰問しているの であるが，答弁する人間は客観・正確な画面を放送し ているが，それが時代の風潮というような主観・曖昧 な情緒を自然に伝達していると抗弁しているという関 係になる。しかし，ここには情報と情緒という分類だ けでは説明できない, もうひとつの重要な要因があ る。

現代の情報社会の基礎となる重要な理論はいくつか あるが, そのひとつはアメリカの学者クロード・シャ ノンが 1948 年に発表した「通信の数学理論」という論 文である。ここでシャノンは情報の量的側面を 2 進表 記で記述するという重要な貢献と同時に, 通信媒体を 経由して事象を伝達するときに，伝達すべきシグナル (信号) と, 不要であるが付随して発生するノイズ (雑 音）とを区別し，いかに前者を効率良く伝達するかが 通信理論の目的関数であると定義した.すなわち, 信 号と雑音の割合である SN 比を向上させることが技術 の目標としたのである.

この思考方法を援用すれば, 情報の伝達媒体は信号 を伝達することが使命である，たしかに，テレビの画 面は初期には信号だけを伝達する意図が明瞭であった が, 最近になり次第に変化してきた。ニュース番組の
変化は好例である．初期のテレビ放送のニュース番組 は無地の背景の前面でアナウンサーが原稿を朗読する という様式であった，ところが，エレクトロニクスニ ユースギャザリング (ENG) とかサテライトニュース ギャザリング $(\mathrm{SNG})$ といわれる技術が急速に普及し， 事件の現場を録画した画像情報や現場から中継で送信 されてくる画像情報がニュース番組のなかに出現する ようになると, アナウンサーが朗読する音声は脇役に なり，画像が主役として登場するようになった．

この主役になった画像がニュースに重大な変化をも たらしているのである。その変化を議員の収賄容疑を 報道するニュース番組で検討してみる．アナウンサー が朗読する音声情報では, 収賄の時期や金額などの数 字とともに，容疑についての質問には議員が否定した というような「客観」かつ「正確」な情報が報道され るのみである。ところが，画像情報により記者に質問 される議員の様子が放映されるようになると事情が変 化してくる。ある議員は質問する記者に不快な目付き で乱暴な言葉で否定し，ある議員は笑顔で明確に否定 している。どちらも音声情報では容疑を否定しました という内容になるが，画像情報を視聴した市民には両 者は大幅に相達した印象をもたらしている。これまで は否定したという情報が信号であり，そのときの態度 は雑音でしかなかったのであるが，その雑音が議員に ついての「主観」かつ「曖昧」な情緒を決定している のである。しかも重要なことは，その社会に浸透する 情緒が議員の運命を左右するまでに影響を持つという 事実である。

このように検討してみると，画像情報は意図すると しないとにかかわらず「どういうことを話合っている かということと関係ないあるイメージを伝達」してい たのである.かつての政治討論の公開番組は，あらか じめ予告された質問を出席の議員に順番にしていく方 式で実行されていたから，どのような質問にも議員は 余裕をもって笑顔で応答することが可能であった．と ころが, 最近の筋書きなしの臨機応変な討論が放送さ れるようになると, 失礼な質問に一瞬不快な顔付をし たり，一瞬回答に躊躇したりする様子が克明に全国に 放送されていく，この顔付きや躊躇は，回答の内容を 信号とすれば雑音でしかないはずであるが，社会は， それらの雑音によって答弁の内容の真偽さえ判断する ようになっているのである.どちらが重要かの判断は 微妙であるが, 前者の番組が 1 桁前半の低視聴率であ るのに対比して, 後者の番組は, ときとして 2 桁の高 視聴率になる事実が社会の評価を明示している.

このような変化は放送番組だけではなく, 日常生活 
にも浸透していくと予測される．音声情報しか伝達し ない現在の電話では, 不快な相手に不快な表情をしな がら音声のみは丁寧に応対することも可能である．し かし，ギガ社会になり，画像情報を伝達するテレビ電 話で応答するようになると, 一瞬の不快な目付や一瞬 の口元の変化が言葉とは裏腹の情緒を伝達することは 確実である．雑音でしかないはずの情報が会話の成否 を左右するのである.

メガ社会までは「信号」を中心とした「情報」が主 役の時代であった。しかし，ギガ社会となって信号以 上の膨大な雑音が社会のなかに放出される時代になっ てみると, その余計なものであった「雑音」が伝達す る「情緒」が社会を左右していることになったのであ る、メが社会を文字と音声を基礎とする信号が情報を 伝達する社会とすると, ギガ社会は画像の内部にある 雑音が情緒を伝達する社会といっていい。 そのように 分析してみると, 画像中心社会となるギガ社会は, 情 報処理や情報伝達が 1000 倍に拡大したという, 従来 のキロ社会やメガ社会の単純な延長線上にあるのでは なく, 別種の構造を持った新規の社会が展開すると理 解する必要がある。

(1994 年 1 月 19 日受付)

\section{【参考 文 献〕}

1） R. フライバーガー, M. スワイン: “パソコン革命の英雄た ち”, マグロウヒル (1985)

2) SE 編集部: “僕らのパソコン 10 年史”, 翔泳社 (1989)

3） NTT 技術動向研究会：“2005 年の情報通信技術”, NTT 出 版 (1990)

4）立川敬二 (編著)：“高度情報社会の基盤テクノロジー”, NTT 出版 (1991)

5） M. ホール, J. バリー：“サン・マイクロシステムズ”, アスキ 一出版局 (1991)

6）通商産業省機械情報産業局新映像産業室：“人間情報社会の 実現に向けて”, 通商産業調查会 (1992)

7）根本英幸, 松岡功：“サン・マイクロシステムズの戦略”,にっ かん書房 (1992)

8）月尾嘉男：“時代は「情報」から「情緒」へ転換する”, エコノ ミスト (Apr. 28, 1992)

9）月尾嘉男：“贅沢の創造：21 世紀・技術は芸術を目指す”, PHP 研究所 (1993)

10）田原総一朗：“TV が決める政治”, 文藝春秋（Sep. 1993）

11) “デジタル・フューチャーの衝撃”, 日経パソコン (Dec. 11, 1993)

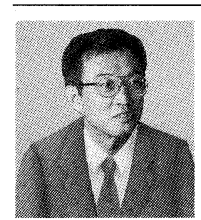

月尾 䕒势 昭和 40 年, 東京大学工学部 卒業. 昭和 51 年, 名古屋大学工学部助教授, 昭和 63 年, 名古屋大学工学部教授, 平成 3 年, 東京大学工学部教授. 専門は生産システ ム, 設計システム。

\section{新刊图書}

\section{MARUZEN Advanced Technology}

\section{一電子・情報・通信編 ディジタル信号処理}

\section{羽鳥光俊・持田侑宏 編}

最近のディジタル技術の進歩は目覚ましいが，それを 支える基盤技術としてディジタル信号処理は，ますます 重要になっている.ディジタル信号処理に関する教科書 的な著書は，すでに数多く出版されているが，そのほと んどは, ディジタル信号処理の基礎理論に多くのページ を割いている，応用技術は広範囲に亘る上に, 進歩が早 く変化も激しいため, 基礎から応用までをバランスよく
記述した書物は少なかった．本書では基礎理論，中でも 適応処理に関して詳しく説明されているほか, 最新の応 用技術について要領よく解説されている点に類書にない 特徵がある.データ圧縮を含む音声処理・動画像処置, さらにファクシミリ・加入者線伝送路・データモデムに おける信号処理から DSP の LSI 化に至るまで, 幅広く 解説されており, これからディジタル信号処理を学ぼう とする読者にとっては格好の入門書となる。また，参考 文献も豊富に掲載されているので, すでにディジタル信 号処理を業務としている読者にとっても座右の書となる 良書と言えよう。

紹介 橋本慶隆 (ソニー)

丸善刊 (1994 年 1 月 31 日発行), A 5 判, 306 頁, 定価 7,931 円(税込) 